\title{
Influence of Timing of Harvest in Relation to Haulm Killing and Planting Date on Potato Tuber Rot Caused by Phytophthora infestans
}

\author{
J. S. Miller and T. F. Cummings, Department of Plant Pathology, L. J. Mikitzel, Department of Horticulture and \\ Landscape Architecture, and D. A. Johnson, Department of Plant Pathology, Washington State University, Pullman \\ 99164-6414
}

\begin{abstract}
Miller, J. S., Cummings, T. F., Mikitzel, L. J., and Johnson, D. A. 2002. Influence of timing of harvest in relation to haulm killing and planting date on potato tuber rot caused by Phytophthora infestans. Plant Dis. 86:264-268.

Killing potato haulms 2 to 3 weeks prior to harvesting tubers is recommended for the management of potato late blight to eliminate the foliage as a source of tuber blight inoculum. Some potato growers in the Columbia Basin of Washington and Oregon, however, harvest tubers within days of killing potato haulms or harvest tubers without killing potato haulms. The susceptibility of potato tubers harvested from green haulms to late blight is unknown. From 1996 to 1998, Russet Burbank and Ranger Russet seed tuber pieces were planted on three different dates and then harvested simultaneously to obtain daughter tubers at different levels of maturity as determined by physiological degree day (P-day) accumulation. Tubers from two trials in 1996 were harvested within 1 to 4 days of haulm killing, tubers from a single trial in 1997 were harvested 16 days after haulm killing, and tubers from two trials in 1998 were harvested 1 and 21 days after haulm killing. Tubers from each plot were divided into two samples; one sample was inoculated the day after harvest and the other sample was inoculated 6 months after harvest on the buds and periderm tissue with a US-8 isolate of Phytophthora infestans. Severity of tuber blight on tuber surfaces and internal tuber tissue was highly correlated. When tubers were harvested within 1 to 4 days after haulm kill, the youngest tubers had the highest percentage of skinning and the lowest percentage of tuber blight. These tests, however, were not designed to test the hypothesis that increased tuber skinning resulted in increased tuber rot. Severity of tuber blight was greater for Ranger Russet tubers than for Russet Burbank tubers. The correlation between the severity of tuber blight at harvest and after 6 months in storage was significant. In some cases, differences in susceptibility to tuber blight due to planting date were observed after 6 months in storage. When tubers were harvested within 1 to 4 days after vine killing, tubers from plants that had been growing longer were more susceptible to late blight tuber rot than tubers from plants that had been growing for a shorter period of time.
\end{abstract}

Additional keywords: late blight

Late blight of potato, caused by Phytophthora infestans (Mont.) de Bary, is a serious problem of commercial potato production. Management of late blight on

Corresponding author: J. Miller

E-mail: jsmiller@uidaho.edu

Current address of first author: Department of Plant, Soil, and Entomological Sciences, University of Idaho, Aberdeen 83210-0870.

Current address of third author: Potato Development Centre, Wicklow, New Brunswick, Canada E7L 3S4.

Plant Pathology New Series 0279, Department of Plant Pathology, College of Agriculture and Home Economics Research Center, Project No. 0678, Washington State University, Pullman 991646430 .

A portion of this research was funded by the Washington Potato Commission.

Accepted for publication 14 November 2001.

Publication no. D-2002-0114-03R

(C) 2002 The American Phytopathological Society foliage is essential to reduce the incidence and severity of the tuber blight phase of the disease $(1,21)$. Tuber blight occurs when sporangia produced on leaf and stem lesions are washed into the soil and cause tuber infections. Consequently, current recommendations call for mechanically or chemically killing haulms 2 to 3 weeks prior to tuber harvest to eliminate $P$. infestans in foliage, thereby removing this source of inoculum (21).

Investigations on tuber blight indicate that tubers become infected through wounds, buds, lenticels, and intact skin $(10,16)$. Wounds were considered most susceptible, buds and lenticels moderately susceptible, and intact skin the least susceptible to infection by $P$. infestans. Harvesting tubers prior to natural haulm senescence often leads to greater tuber rot, suggesting that tuber resistance increased as tubers matured $(1,2,7,11,22,23)$.

Bonde and Shultz (1) observed that the number of blighted tubers was greatest when tubers were harvested prior to the death of blighted haulms, compared with tubers harvested following the death of blighted haulms. Lacey (11) found that more lenticels than buds became infected when tubers were spray inoculated with $P$. infestans. Lenticels became more resistant to infection as tubers matured, possibly from the suberization of lenticels that occurs at maturity. Infections did not occur through intact periderm. Stewart et al. (22) and Zan (23) observed that lenticel infection decreased with increased tuber age. Lenticel suberization generally increases during the growing season, but can be influenced by cultivar and soil conditions (23). In contrast, buds become more susceptible with age (11). Lacey (11) observed that, when tubers became infected in soil from naturally occurring inoculum, buds were the primary infection point four times more often than lenticels. If buds are the primary infection sites in soil, and bud susceptibility increases near the end of the season, then an increase in tuber susceptibility at the end of the growing season could be expected. Indeed, whole tuber susceptibility has been reported to increase near the end of the growing season (2), but tuber blight susceptibility has been reported to decrease once tubers are lifted from soil (22).

Susceptibility of tubers in storage has been reported to decrease $(18,23)$, to increase initially then decrease (7), and to increase (9). The different results in these studies may have resulted from the method of evaluating tuber susceptibility to late blight. Dorrance and Inglis (4), for example, compared tuber susceptibility of whole tubers and tuber slices and found whole tubers were more reliable based on reduced variation in year-to-year test results. Contradictory information on tuber susceptibility in storage also could be influenced by the degree of tuber wounding incurred at harvest, the interval from harvest to inoculation, and the duration of tuber storage prior to susceptibility testing. Physiological properties of tubers related to disease susceptibility, such as suberin formation and integrity of cortical tissues, are dynamic during the storage period. Suberin formation, which occurs after wounding and at tuber maturity, increases in storage, resulting in decreased tuber susceptibility to $P$. infestans (15). Tuber susceptibility to late blight is decreased in potato tubers by the outer 20 to 30 layers of cortical tissue. The efficacy of this cortical layer barrier 
decreases during storage (17). Dorrance and Inglis (4) observed that pre- and poststorage evaluations gave a better measure of tuber resistance than a single prestorage rating alone. Prestorage ratings could indicate tuber resistance conferred by skin set and tuber maturity, whereas poststorage ratings could indicate the effects of aging and suberin formation on tuber resistance.

The benefits of delaying harvest for 2 to 3 weeks after killing potato haulms by mechanical or chemical means are obvious when foliage is infected with $P$. infestans. It is not clear if a delay between haulm killing and harvest is needed for the management of tuber blight under conditions of low foliar disease incidence in the semiarid climate that occurs in the Columbia Basin of Oregon and Washington. Traditionally, many potato growers in the Columbia Basin have harvested tubers within 1 to 2 days of haulm killing, or have not killed potato haulms prior to harvest, and have chosen instead to either let plants senesce naturally or to harvest with green foliage. The relative susceptibility to late blight of tubers harvested from haulms killed a day prior to harvest compared with tubers harvested from haulms killed 2 to 3 weeks prior to harvest is unknown. In semiarid environments, harvesting tubers without haulm killing or shortly after haulm death may result in tubers that are more resistant to infection by $P$. infestans through buds compared with tubers harvested 2 or 3 weeks after haulm killing. The purposes of this study were to test the hypothesis that tubers harvested from younger foliage are less susceptible to $P$. infestans infection than tubers from older haulms, and to determine if tuber susceptibility to late blight evaluated at harvest was similar to susceptibility after 6 months in storage.

\section{MATERIALS AND METHODS}

Field tests. Trials were conducted from 1996 to 1998 on a Shano silt loam soil at the Washington State University (WSU) Research Unit near Othello, WA. Certified potato seed tubers of cvs. Russet Burbank and Ranger Russet were cut into approximately 60-g seed pieces and hand planted in plots $6 \mathrm{~m}$ long with a $25-\mathrm{cm}$ spacing within row and $86-\mathrm{cm}$ spacing between rows. Seed pieces of each cultivar were planted on three dates each year in a split block arrangement of treatments using a randomized complete block design with six replications. Planting, haulm killing, and harvest dates are outlined in Table 1 . The trial was duplicated in two fields in 1996, carried out in a single field in 1997, and duplicated in two fields in 1998. NPK fertilizer was applied preplant and through irrigation water as required during the growing season. In 1996 and 1998, 1,3dichloropropene (Telone II, Dow Agrisciences, Indianapolis, IN) was applied at a rate of 189 liters/ha for control of plant parasitic nematodes. Preplant herbicides dipropylthiocarbamate (Eptam 7-E, Zeneca Ag Products, Wilmington, DE) at a rate of 4.14 liters/ha and pendimethalin (Prowl 3.3 EC, BASF, Research Triangle Park, NC) at a rate of 1.18 liters/ha were applied to all fields for weed control. Chlorothalonil (1.77 liters/ha; Bravo WeatherStik, Zeneca Ag Products) was rotated with mancozeb $(2.28 \mathrm{~kg} / \mathrm{ha}$; Dithane $75 \mathrm{DF}$, Rohm and Haas, Co., Philadelphia, PA) on a weekly basis to protect the foliage from natural infection by $P$. infestans. Foliar late blight symptoms were never observed in any of the fields. In 1996 and 1997, esfenvalerate (Asana XL, Dupont Crop Protection, Wilmington, DE) was applied at a rate of 0.43 liters/ha to suppress insect pests. Overhead irrigation in the amount of $140 \mathrm{~cm}$ was applied to plots each year.

The climatic variables of air temperature (recorded at $1.5 \mathrm{~m}$ above ground) and precipitation were obtained from a weather station located at the WSU Othello Research Unit operated by the Washington Public Agriculture Weather System (PAWS). Air temperature was recorded every 15 min. Maximum and minimum daily air temperatures were used to calculate physiological degree days (P-days) using the following equation (20):

$P$ day $=\left(\frac{1}{24}\right)\left[\begin{array}{l}5 \times P\left(T_{\text {min }}\right)+8 \times P\left(\frac{2 \times T_{\min }}{3}+\frac{T_{\text {max }}}{3}\right) \\ +8 \times P\left(\frac{2 \times T_{\text {max }}}{3}+\frac{T_{\text {min }}}{3}\right)+3 \times P\left(T_{\text {max }}\right)\end{array}\right]$

where:

$P(T)=0$ when $T<7^{\circ} \mathrm{C}$ and $T \geq 30^{\circ} \mathrm{C}$

$P(T)=10\left[1-\frac{(T-21)^{2}}{(21-7)^{2}}\right]$ when $7 \leq T<21^{\circ} \mathrm{C}$

$P(T)=10\left[1-\frac{(T-21)^{2}}{(30-21)^{2}}\right]$ when $21 \leq T<30^{\circ} \mathrm{C}$

Prior to harvest, potato haulms were killed using a commercial, mechanical vine beater. In 1996, tubers were harvested within 1 to 4 days of haulm killing, while in 1997 there was a 16-day interval. Because of the discrepancy in the interval from haulm-kill to harvest, the experiment

Table 1. Dates of planting, haulm kill, and harvest and accumulated physiological degree days (P-days) of Russet Burbank and Ranger Russet potato tubers planted at three different dates from 1996 to 1998 at Othello, WA ${ }^{\mathrm{a}}$

\begin{tabular}{|c|c|c|c|c|c|}
\hline \multicolumn{2}{|l|}{ Planting } & \multicolumn{2}{|c|}{ Haulm kill $^{\mathbf{b}}$} & \multicolumn{2}{|c|}{ Harvest $^{\mathbf{c}}$} \\
\hline Location, time & Date & Date & P-days & Date & P-days \\
\hline \multicolumn{6}{|l|}{1996 field 1} \\
\hline Early & April 25 & September 6 & 844 & September 10 & 873 \\
\hline Mid & May 16 & September 6 & 761 & September 10 & 790 \\
\hline Late & June 5 & September 6 & 648 & September 10 & 677 \\
\hline \multicolumn{6}{|l|}{1996 field 2} \\
\hline Early & April 15 & September 24 & 965 & September 25 & 972 \\
\hline Mid & May 16 & September 24 & 882 & September 25 & 889 \\
\hline Late & June 5 & September 24 & 769 & September 25 & 776 \\
\hline \multicolumn{6}{|l|}{1997} \\
\hline Early & April 11 & September 8 & 1,027 & September 24 & 1,135 \\
\hline Mid & May 5 & September 8 & 939 & September 24 & 1,047 \\
\hline Late & May 29 & September 8 & 780 & September 24 & 888 \\
\hline \multicolumn{6}{|l|}{1998 field 1} \\
\hline Early & April 30 & September 8 & 903 & September 9 & 911 \\
\hline Mid & May 19 & September 8 & 794 & September 9 & 802 \\
\hline Late & Jun 9 & September 8 & 661 & September 9 & 669 \\
\hline \multicolumn{6}{|l|}{1998 field 2} \\
\hline Early & April 30 & September 8 & 903 & September 29 & 1,054 \\
\hline Mid & May 19 & September 8 & 794 & September 29 & 945 \\
\hline Late & Jun 9 & September 8 & 661 & September 29 & 812 \\
\hline
\end{tabular}

${ }^{a}$ P-days (20) calculated as $P$-day $=(1 / 24)\left[5 \times P\left(T_{\min }\right)+8 \times P\left(2 \times T_{\min } / 3+T_{\max } / 3\right)+8 \times P\left(T_{\min } / 3+2 \times T_{\max } / 3\right)+3 \times P\left(T_{\max }\right)\right] ; P(T)=0$ when $T<7^{\circ} \mathrm{C}$ or when $T \geq 30^{\circ} \mathrm{C} ; P(T)=10\left[1-\left(T-21^{\circ} \mathrm{C}\right)^{2} /(21-7)^{2}\right]$ when $7 \leq T<21^{\circ} \mathrm{C}$; and $P(T)=10\left[1-\left(T-21^{\circ} \mathrm{C}\right)^{2} /(30-21)^{2}\right]$ when $21 \leq T<30^{\circ} \mathrm{C}$.

${ }^{\mathrm{b}}$ Haulms were killed using a commercial, mechanical vine beater.

c Tubers were harvested using a small plot potato harvester. 
was repeated twice in 1998; one field (designated as field 1) was harvested the day after haulm kill and the second field (desfollowing haulm kill. Tubers were harvested using a small plot potato harvester (which simulated a commercial potato harvester), washed immediately, air dried, and evaluated for skinning (percentage of surface area with damaged periderm). Tubers were transported to Pullman, WA and either inoculated with $P$. infestans within $12 \mathrm{~h}$ (field sample) or stored at $9^{\circ} \mathrm{C}$ and $95 \%$ relative humidity $(\mathrm{RH})$ for 6 months, then inoculated (storage sample). Tubers selected for inoculation weighed 113 to $227 \mathrm{~g}$ and were stored in mesh bags in a completely randomized design.

Inoculum production and tuber inoculation. Two US-8 (6) isolates of $P$. infestans, CF1 and 584-1, were used for inoculations. Isolate $\mathrm{CF} 1$ was collected from the Columbia Basin in 1996 by the authors, and isolate 584-1 (collected from the Columbia Basin in 1994) was supplied by Philip B. Hamm, Oregon State University, Irrigated Research Station in Hermiston. Isolate genotypes were identified on the basis of mating type, allozyme phenotype (glucose phosphate isomerase and peptidase), and DNA fingerprint $(5,13)$. All isolates were grown on potato leaves and tuber slices once each year and reisolated in pure culture to maintain pathogenicity. Isolate 584-1 was used in 1996 due to prolific sporangia production. Isolate $\mathrm{CF} 1$ was used in 1997 and 1998 for the same reason. Isolates were maintained on rye extract agar at $18^{\circ} \mathrm{C}$ in the dark for long-term storage.

Inoculum of $P$. infestans was increased on either tuber slices (1996) or detached leaves (1997 and 1998). Tuber slices (cv. Russet Norkotah) were cut $1 \mathrm{~cm}$ thick and placed in 20-by-100-mm glass petri dishes containing a 9-cm Whatman no. 1 filter paper moistened with $5 \mathrm{ml}$ of distilled, deionized water. A sporangial suspension was created by flooding a 2- to 3-week-old culture grown on rye extract agar with distilled, deionized water, and scraping ignated as field 2) was harvested 20 days

with a small spatula to dislodge sporangia. Three drops of the suspension were then placed on a tuber slice. Cultures on tuber slices were incubated at $18^{\circ} \mathrm{C}$ for 6 to 7 days in darkness. Sporangia were obtained by scraping mycelia from infected tuber slices into a beaker containing $15 \mathrm{ml}$ of distilled, deionized water. The suspension was stirred to dislodge sporangia, then strained through three layers of cheesecloth. The sporangial suspension was then incubated at $4^{\circ} \mathrm{C}$ for $2 \mathrm{~h}$ to induce zoospore formation. In 1997 and 1998, inoculum was obtained from detached leaves. The petiole of detached leaves (cv. Russet Norkotah) was inserted into 22-ml glass test tubes containing $20 \mathrm{ml}$ of distilled water. Test tubes then were placed in a test tube rack and the detached leaves were misted with distilled water using a handpump sprayer. Three drops of the sporangial suspension was placed on individual leaflets. Leaves were incubated at $18^{\circ} \mathrm{C}$ for 5 to 6 days with an 18-h photoperiod. Sporangia were washed from infected, sporulating detached leaves with distilled, deionized water and the suspension then was chilled at $4{ }^{\circ} \mathrm{C}$ for $2 \mathrm{~h}$ to induce zoospore formation. All sporangial suspensions, whether derived from tuber slices or detached leaves, were adjusted to $1 \times 10^{4}$ sporangia/ml with distilled, deionized water and counted using a hemacytometer.

Tubers were dipped in distilled water, then inoculated by placing a $1-\mathrm{cm}^{2}$ piece of filter paper wetted with a $50-\mu l$ drop of sporangial suspension (approximately 500 sporangia/drop) over a bud and another over periderm tissue of each tuber. Filter paper wetted with sterile water was used for the control. Two to four tubers (subsamples) were inoculated for each plot and incubated in a misting chamber for $18 \mathrm{~h}$ at 18 to $21^{\circ} \mathrm{C}$. The chamber was misted for 1 min every $20 \mathrm{~min}$.

After the 18-h incubation period, tubers were allowed to air dry for $24 \mathrm{~h}$ and then were placed in storage at $9^{\circ} \mathrm{C}(95 \% \mathrm{RH})$. Tubers were evaluated 4 to 5 weeks later for external and internal tuber blight severity. External tuber blight severity was es-

Table 2. Effect of planting date and potato cultivar on the percentage of tuber surface that was skinned at harvest

\begin{tabular}{lcccc}
\hline & \multicolumn{4}{c}{ Percentage of tuber surface skinned $^{\mathbf{a}}$} \\
\cline { 2 - 5 } Variables & $\mathbf{1 9 9 6}^{\text {field 2 }}$ & $\mathbf{1 9 9 7}$ & $\mathbf{1 9 9 8}_{\text {field } \mathbf{~}}$ & $\mathbf{1 9 9 8}^{\text {field 2 }}$ \\
\hline Planting date & & & & \\
Early & 15 & 8 & 9 & 8 \\
Mid & 23 & 5 & 13 & 7 \\
Late & 36 & 3 & 17 & 6 \\
LSD $(P=0.05)^{\mathrm{c}}$ & 5 & 3 & 3 & NS \\
Cultivar & & & 13 & 7 \\
Ranger Russet & 31 & 6 & 13 & 7 \\
Russet Burbank & 19 & 5 & NS & NS \\
LSD $(P=0.05)^{\mathrm{c}}$ & 4 & NS &
\end{tabular}

a Percentage of missing tuber skin was visually estimated for all tubers harvested from a plot as the tubers rolled over a sorting table.

b Planting date refers to the sequential order of planting.

${ }^{c}$ Fisher's least significant difference (LSD). NS = not significantly different. timated by peeling the skin to a depth of approximately $3 \mathrm{~mm}$ from the outside of the tuber and visually assessing the percentage of surface area discolored. Tubers then were sliced in half. The two pieces were sliced, parallel to the first cut, which resulted in four tuber pieces that were created from three, parallel cuts. Internal tuber blight severity was estimated by averaging the estimated percentage of discolored tissue at the interface of each cut.

Statistical analysis. Treatments were arranged in a split block with planting date as the whole plot factor and cultivar as the subplot factor (14). Testing for significance of planting date $(P)$, cultivar $(C)$, and interactions among effects was done using analysis of variance (ANOVA) with the following model statement: $Y_{i j k l}=\mu+$ Block $_{i}+P_{j}+(\text { block } \times P)_{i j}($ whole plot $)+$ $C_{k}+(P \times C)^{j k}+(\text { block } \times P \times C)_{i j k}($ subplot).

Values from subsamples were averaged before statistical analyses were performed. Percentages of external and internal tuber blight severity were transformed using the arcsine transformation or using square root transformation when the assumption of equal variance was not met by arcsine transformation (14). Mean separation was performed using the protected Fisher's least significant difference (LSD) test when the $F$ test was significant $(P \leq 0.05)$ for a test factor. The analyses were conducted using PROC GLM procedure of SAS (SAS Institute, Inc., Cary, NC). Pearson's correlation coefficients were calculated to compare external and internal tuber blight severity ratings, and to compare field sample and storage sample ratings using the PROC CORR procedure of SAS.

\section{RESULTS}

The number of accumulated P-days was different among years. Accumulated Pdays for potato plants from planting to haulm kill ranged from 648 to 965 P-days in 1996, 780 to 1,027 P-days in 1997, and 661 to 903 P-days in 1998 (Table 1). During the interval from haulm kill to harvest in 1996, 29 P-days accumulated over 4 days in field 1 and 7 P-days accumulated in 1 day in field 2. In field 1 in 1998, eight $\mathrm{P}$-days accumulated in the 1-day interval from haulm kill to harvest. A total of 108 and 151 P-days accumulated in 1997 and in 1998 in field 2, respectively.

When tubers were harvested within 1 to 4 days after haulm kill (1996 field 2 and 1998 field 1), tubers from the early planting date (the oldest tubers) had the least amount of skinning, whereas those from the late planting date (the youngest tubers) had the greatest amount of skinning (Table 2). In 1997, with 16 days (108 P-days) between haulm kill and harvest, tubers from the early planting date had a larger percentage of skinning than the mid- or late planting dates. Skinning was not significantly different in field 2 in 1998. The 
amount of skinning between Russet Burbank and Ranger Russet tubers was not different, except for tubers harvested in field 2 in 1996 in which Ranger Russet tubers showed more skinning. Skinning data were not recorded for tubers from field 1 in 1996.

Using the inoculation method described in these experiments, all the inoculated tubers became infected. Tubers inoculated with sterile water did not develop symptoms of tuber blight. Interactions among planting dates and cultivars for severity of tuber blight were not significant in any of the trials; therefore, mean separations were performed only on the main effects of cultivar and planting date. Tuber blight severity estimates on the external ratings and internal ratings were highly correlated (Table 3); therefore, only external tuber blight evaluations are presented in Tables 4 and 5 .

Tubers from the late planting date had the lowest severity of tuber blight in both fields in 1996. Severity of tuber blight among planting dates was not significantly different in 1997, or in field 2 in 1998. In field 1 in 1998, tuber blight severity was highest for the mid-planting date and lowest for the late planting date. Severity of tuber blight for tubers from the early planting date was not significantly different from tuber blight severity from either the mid- or late planting dates. Ranger Russet tubers were more susceptible to blight than Russet Burbank tubers from field 1 in 1996, and from both fields in 1998. Severity of tuber blight between cultivars was not significantly different in field 2 in 1996, or in 1997.

When tubers were inoculated after 6 months in storage, severity of tuber blight was significantly different among planting dates from field 1 in 1996 and from field 1 in 1998 (Table 5). In both cases, tubers from plants in the early planting date had greater tuber blight severity than tubers

Table 3. Pearson's correlation coefficients for the percentage of external and internal discoloration of tubers inoculated within 1 day of harvest (field) and of tubers inoculated after 6 months in storage (storage) ${ }^{\mathrm{a}}$

\begin{tabular}{lcc}
\hline & \multicolumn{2}{c}{ Correlation coefficient $^{\mathbf{b}}$} \\
\cline { 2 - 3 } Trial & Field & Storage \\
\hline 1996, field 1 & 0.83782 & 0.94743 \\
1996, field 2 & 0.94556 & 0.94140 \\
1997 & 0.72184 & 0.80692 \\
1998, field 1 & 0.89710 & 0.85129 \\
1998, field 2 & 0.85252 & 0.91121 \\
\hline
\end{tabular}

${ }^{a}$ External discoloration is the percentage of the surface area of the tuber that is discolored. Estimated after removing $3 \mathrm{~mm}$ of skin. Internal discoloration is the average estimate of discolored tissue observed at the interface of each cut on tuber that is sliced in half and then each half is sliced again parallel to the first cut.

b Pearson's correlation coefficients all significant at $P=0.0001$ from the late planting date. Tuber blight severity from the mid-planting date was similar to the tuber blight severity at the early planting date for field 1 in 1996, and similar to tuber blight severity at the late planting date for field 1 in 1998. Russet Burbank tubers inoculated after storage had significantly less tuber blight than Ranger Russet tubers from every field. Severity of tuber blight from field samples and storage samples were correlated in both fields in 1996 and in both fields in 1998, but not in 1997 (Table 6).

\section{DISCUSSION}

Results from both fields in 1996 and field 1 in 1998 indicate that tubers from younger plants (fewer P-days) are less susceptible to late blight than tubers from older plants (more P-days) when tubers are inoculated 1 day after harvest. Tubers from these trials were harvested soon after haulm kill (4 days for field 1 in 1996, 1 day for field 2 in 1996, and 1 day for field 1 in 1998). These data support our hypothesis that tubers from younger potato haulms are less susceptible to $P$. infestans infection than tubers from older haulms. In the Columbia Basin of Washington and Oregon, some potato growers harvest tu- bers 1 to 2 days after haulm killing. Under these circumstances, tubers from plants that have been growing longer may be more susceptible to late blight tuber rot than tubers from plants that have been growing for a shorter period of time. However, the relationship of plant age and harvest interval requires additional investigation. In 1997 and in field 2 in 1998, severity of tuber blight was not different among planting dates. In these two trials, the interval between haulm kill and harvest date was 16 and 21 days, respectively.

An interval of 10 to 14 days between haulm killing and harvest is recommended for skin maturation (19). The data from our tests seem to support this recommendation. Tubers in 1997 and field 2 in 1998 remained in the ground for 16 and 21 days (108 and 151 P-days) after haulm killing, respectively. Some skinning occurred under these conditions, but the percentage of skinning among planting dates was not different from field 2 in 1998 and was small in 1997. On the other hand, in the two trials in which tubers were harvested within 1 to 4 days after haulm killing (field 2 in 1996 and field 1 in 1998), tubers from younger plants had a higher percentage of skinning than tubers from older plants.

Table 4. Percentage of tuber blight for two potato cultivars, planted on three different dates, and inoculated with Phytophthora infestans 1 day after harvest

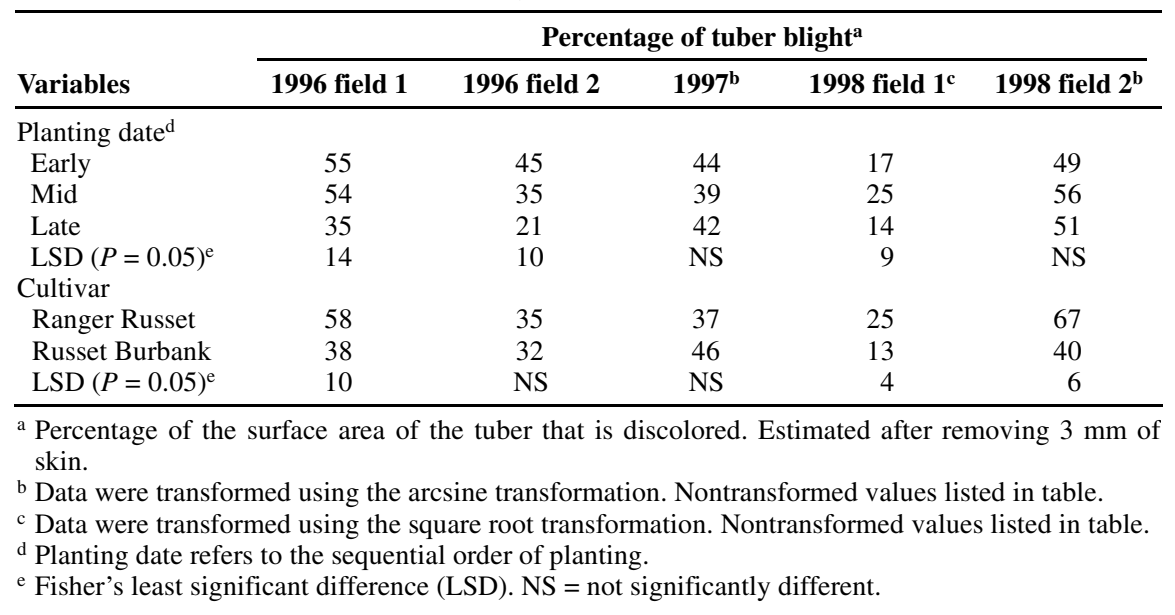

Table 5. Percentage of tuber blight on tubers of two potato cultivars, planted on three different dates, and inoculated with Phytophthora infestans after 6 months in storage

\begin{tabular}{lccccc}
\hline & \multicolumn{5}{c}{ Percentage of tuber blight $^{\mathbf{a}}$} \\
\cline { 2 - 6 } Variables & $\mathbf{1 9 9 6}$ field 1 & $\mathbf{1 9 9 6}$ field 2 & $\mathbf{1 9 9 7}^{\mathbf{b}}$ & $\mathbf{1 9 9 8}_{\text {field 1 }}$ & $\mathbf{1 9 9 8}$ field 2 \\
\hline Planting date & & & & & \\
Early & 33 & 37 & 57 & 30 & 26 \\
Mid & 31 & 31 & 58 & 18 & 26 \\
Late & 9 & 30 & 61 & 21 & 29 \\
LSD $(P=0.05)^{\mathrm{d}}$ & 9 & NS & NS & 6 & NS \\
Cultivar & & 53 & 63 & 29 & 35 \\
Ranger Russet & 41 & 12 & 54 & 16 & 20 \\
Russet Burbank & 5 & 10 & 7 & 4 & 6 \\
LSD $(P=0.05)^{\mathrm{d}}$ & 8 & & & & \\
\hline
\end{tabular}

${ }^{a}$ Percentage of the surface area of the tuber that is discolored. Estimated after removing $3 \mathrm{~mm}$ of skin.

${ }^{\mathrm{b}}$ Data were transformed using the arcsine transformation. Nontransformed values listed in table.

${ }^{c}$ Planting date refers to the sequential order of planting.

${ }^{\mathrm{d}}$ Fisher's least significant difference (LSD). NS = not significantly different. 
Table 6. Pearson's correlation coefficients for severity of tuber blight between tubers inoculated with Phytophthora infestans within 1 day of harvest and tubers inoculated after 6 months in storage ${ }^{\mathrm{a}}$

\begin{tabular}{lc}
\hline Trial & Correlation coefficient $^{\mathbf{b}}$ \\
\hline 1996, field 1 & $0.39091^{* *}$ \\
1996, field 2 & $0.31949^{*}$ \\
1997 & -0.03389 (NS) \\
1998 field 1 & $0.28861^{*}$ \\
1998 field 2 & $0.27461^{*}$ \\
\hline
\end{tabular}

${ }^{a}$ Severity measured as percentage of the surface area of the tuber that is discolored. Estimated after removing $3 \mathrm{~mm}$ of skin.

b $* *=P<0.001, *=P<0.01, \mathrm{NS}=P \geq 0.05$.

Recommendations for managing tubers prior to harvest call for practices that promote a solid, stable tuber skin in order to avoid injury at harvest and to reduce bacterial and fungal disease such as late blight (19). We expected the tubers that were more prone to periderm damage (skinning) to be more susceptible to late blight; however, tubers inoculated 1 day after harvest from treatments that had the greatest percentage of skinning did not have the highest percentage of tuber blight. Although a relationship may exist between the degree of skinning and the susceptibility of tubers to late blight, the susceptibility of tubers that were actually skinned to late blight was not tested. A previous study showed that wounded tubers are more susceptible to late blight than nonwounded tubers (16).

In this study, tubers retained some resistance to tuber blight after storage for 6 months. Other studies have suggested that resistance due to maturity at harvest was temporary and dissipated after storage (12), and that tuber resistance to late blight declined in storage after tuber dormancy ended (3). In four of the five trials of this study, the percentage of blight on tubers inoculated at harvest was correlated with the percentage of blight after 6 months in storage. The correlations between assays at harvest (field sample) and after storage (storage sample), however, were weak $\left(R^{2}\right.$ of 0.27 to 0.39 ) and indicate that evaluating tuber susceptibility at harvest may not provide a complete assessment of the susceptibility of tubers to late blight throughout storage. Dorrance and Inglis (4) indicated that evaluations on tuber late blight susceptibility both at harvest and after storage are needed to accurately estimate susceptibility of tubers to late blight.

Russet Burbank tubers generally were more resistant to tuber blight than Ranger Russet tubers. Dorrance and Inglis (4) found that Russet Burbank tubers were consistently more resistant than Ranger Russet tubers in field ratings and in tuber slice assays, but not in whole tuber assays. The data from our study indicate that culti- var differences may be more pronounced after storage. In 1996 from field 1 and in 1997, tuber blight was not significantly different between the two cultivars at harvest, but Ranger Russet tubers were more susceptible to tuber blight after 6 months in storage. Inglis and Johnson (9) reported that Ranger Russet tubers had a high incidence of tuber infection 3 months after storage.

The inoculation technique utilized in this study was highly effective. All inoculated tubers developed symptoms. Placing contaminated filter paper over tuber buds ensured that sporangia and zoospores were in close contact with susceptible tissue during the incubation period. This inoculation procedure is simple and reliable. Dorrance and Inglis (4) showed that whole tuber assays were more effective than tuber slice assays in determining cultivar resistance rankings due to the reduced variation within treatments present in the whole tuber assays.

Additional research is needed to directly compare tuber susceptibility to late blight for tubers harvested a day after haulm killing with tubers harvested 2 to 3 weeks after haulm killing. With our data, a direct comparison cannot be made between tubers harvested within 1 to 4 days of haulm kill and tubers harvested 16 to 20 days after haulm kill, because tubers were harvested and inoculations were made on different dates. Research also is needed to determine how varying levels of late blight infestation in potato haulms would influence tuber infection when tubers are harvested within a day of haulm killing. Harvesting tubers within 1 to 4 days after haulm killing, or without haulm killing, would give the benefits of increased yield and tuber quality (8) and economical savings (cost of desiccant).

\section{ACKNOWLEDGMENTS}

We thank R. Thornton for his helpful suggestions; R. Alldredge for statistical consultation; N. Fuller, D. Vargas, and S. Dover for technical assistance; and L. M. Carris, G. S. Campbell, and R. E. Thornton for their critical review of the manuscript.

\section{LITERATURE CITED}

1. Bonde, R., and Schultz, E. S. 1945. The control of potato late blight tuber rot. Am. Potato J. 22:163-167.

2. Boyd, A. E. W., and Henderson, J. M. 1953. Susceptibility of immature potato tubers to blight. Plant Pathol. 2:113-116.

3. Chalenko, G. I., Leont'eva, G. V., Yurganova, L. A., Karavaena, K. A., and Ozeretskovskaya, O. L. 1980. Resistance of potato tubers to Phytophthora infestans during storage. Appl. Biochem. Microbiol. 16:194-199.

4. Dorrance, A. E., and Inglis, D. A. 1998. Assessment of laboratory methods for evaluating potato tubers for resistance to late blight. Plant Dis. 82:442-446.

5. Goodwin, S. B., Drenth, A., and Fry, W. E. 1992. Cloning and genetic analyses of two highly polymorphic, moderately repetitive nuclear DNAs from Phytophthora infestans. Curr. Genet. 22:107-115.

6. Goodwin, S. B., Sujkowski, L. S., Dyer, A. T., Fry, B. A., and Fry, W. E. 1995. Direct detection of gene flow and probable sexual reproduction of Phytophthora infestans in northern North America. Phytopathology 85:473-479.

7. Grinberger, M., Kadish, D., and Cohen, Y. 1995. Infectivity of metalaxyl-sensitive and resistant isolates of Phytophthora infestans to whole potato tubers as affected by tuber aging and storage. Phytoparasitica 23:165-175.

8. Halderson, J. L., Haderlie, L. C., and Corsini, D. L. 1985. Potato vine kill: Pulling, chemical killing and rolling effects on yield and quality of Russet Burbank. Am. Potato J. 62:281-288.

9. Inglis, D. A., and Johnson, D. A. 1994 Evaluation of potato cultivars grown in the Pacific Northwest for resistance to late blight. (Abstr.) Am. Potato J. 71:679.

10. Jones, L. R., Giddings, N. J., and Lutman, B. F. 1912. Investigations of the potato fungus Phytophthora infestans. Vt. Agric. Exp. Stn. Bull. 168.

11. Lacey, J. 1967. Susceptibility of potato tubers to infection by Phytophthora infestans. Ann. Appl. Biol. 59:257-264

12. McGee, M., Jarvis, M. C., and Duncan, H. J. 1985. Wound healing in potato tuber tissue. 1 Effects of maturity at harvest. Potato Res. 28:91-99.

13. Miller, J. S., Hamm, P. B., and Johnson, D. A 1997. Characterization of the Phytophthora infestans population in the Columbia Basin of Oregon and Washington from 1992 to 1995. Phytopathology 87:656-660.

14. Milliken, G. A., and Johnson, D. E. 1992 Analysis of Messy Data. Chapman and Hall, New York.

15. Müller, K. O. 1957. Wound healing of the potato tuber in relation to infection by $P h y$ tophthora infestans (Mont.) de Bary. Aust. J. Biol. Sci. 10:189-196.

16. Murphy, P. A., and McKay, R. 1925. Further experiments on the sources and development of blight infection in potato tubers. J. Dep. Lands Agric. (Irel.) 25:10.

17. Pathak, N., and Clarke, D. D. 1987. Studies on the resistance of the outer cortical tissues of the tubers of some potato cultivars to Phytophthora infestans. Physiol. Mol. Plant Pathol. 31:123-132.

18. Platt, H. W. 1994. Foliar application of fungicides affects occurrence of potato tuber rots caused by four foliar pathogens. Can. J. Plant Pathol. 16:341-346.

19. Plissey, E. S. 1993. Maintaining tuber health during harvest, storage, and post-storage handling. Pages 41-53 in: Potato Health Management. R. C. Rowe, ed. American Phytopathological Society, St. Paul, MN.

20. Sands, P. J., Hackett, C., and Nix, H. A. 1979. Model of the development and bulking of potatoes (Solanum tuberosum L.). Field Crops Res. 2:309-331.

21. Stevenson, W. R. 1993. Management of early blight and late blight. Pages 141-147 in: Potato Health Management. R. C. Rowe, ed American Phytopathological Society, St. Paul, MN.

22. Stewart, H. E., McCalmont, D. C., and Wastie, R. L. 1983. The effect of harvest date and the interval between harvest and inoculation on the assessment of the resistance of potato tubers to late blight. Potato Res. 26:101-107.

23. Zan, K. 1962. Activity of Phytophthora infestans in soil in relation to tuber infection. Trans. Br. Mycol. Soc. 45:205-221. 